illustrated; Les Bases physico-chimiques de la Chimie analytique, Herz, illustrated; La Théorie des Courants alternatifs, A. Russell, illustrated. Harper and Brothers. -The Life of the Universe, Prof. Svante Arrhenius. Longmans and Co.-Spinning Tops and Gyroscopic Motion, H. Crabtree, illustrated; Electric Furnaces: the Production of Heat from Electrical Energy and the Construction of Electric Furnaces, Prof. W. Borchers, translated by H. G. Solomon, part ii., illustrated. Macmillan and Co., Ltd.-Physical Science in the Time of Nero: being a Translation of Seneca's "Quæstiones Naturales," J. Clarke, with notes on the subject-matter by Sir A. Geikie, K.C.B., P.R.S. John Murray.-The Interpretation of Radium, F. Soddy (The Progressive Science Series), with diagrams. The Oxford University Press.-Elements of Non-Euclidean Geometry, B. J. L. Coolidge. Kegan Paul and Co., Ltd.-Music: its Laws and Evolution, J. Combarieu (International Science Series); Periodic Law, A. E. Garrett (International Science Series). The Rationalist Press Association, L.td.-The History of Astronomy, Prof. G. Forbes, F.R.S. The University Tutorial Press, Ltd.Geometry, Theoretical and Practical, section vi., Solid Geometry (Euclid xi.), W. P. Workman and A. G. Cracknell.

\section{Medical Science.}

F. Alcan (Paris).-Le Diabète sucré, Lepine; Les aliénés Voyageurs, Joffroy and Dupouy. Baillière, Tindall and Cox.-Differential Diagnosis of Bacteriology, E. P. Minett and R. C. P. London. Cassell and Co., Ltd.Health and Common Sense, W. Hutchinson; Mind and Work, M. H. Gulick; Parenthood and Race-culture : an Outline of Eugenics, Dr. C. W. Saleeby. A. Constable and Co., Ltd.-The Fluids of the Body, Prof. E. H. Starling, F.R.S. John Lane.-The Medical Diseases of Children, R. Miller. Methuen and Co.-Drugs and the Drug Habit: Chapters on the Dynamics of a Remedial Particle, Dr. H. Sainsbury. John Murray.-Children in Health and Disease, Dr. D. Forsyth; Problems in Animal Metabolism, J. B. Leathes (new edition). J. Nisbet and Co., Ltd.-Injuries and Diseases of the Knee-joint, considered from the Clinical Aspect, Sir W. H. Bennett, illustrated; Movable Kidney, W. Arbuthnot; Hip Disease in the Young, J. Berry; Prostatectomy, J. W. T. Walker; Enuresis, J. H. Thursfield; Some of the Common Affecrions of the Tongue, J. Hutchinson; Some Clinical Points in the Surgery of the Intestine, F. C. Wallis; The Operative Treatment of Chronic Constipation, W. A. Lane, illustrated. G. P. Putnam's Sons.-The Art of Natural Sleep, with Definite Directions for the Wholesome Cure of Sleeplessness, illustrated by Cases Treated, L. P. Powell. Rebman, Ltd.-Text-book of Special Pathology, Drs. Beattie and Dickson, illustrated; Text-book of Hyperæmia as Applied in Medicine and Surgery, Prof. A. Bier, authorised translation from the fifth revised German edition by Dr. G. N. Blech, illustrated; Atlas of Clinical Surgery, with Special Reference to Diagnosis and Treatment, for Practitioners and Students, Dr. P. Bockenheimer, English adaptation by Dr. C. F. Marshall, 3 vols., illustrated; Surgery of the Upper Abdomen, Drs. Deaver and Ashhurst, in two volumes, vol. i., Surgery of the Stomach and Duodenum; vol. ii., Surgery of the Liver, Gall Bladder, Pancreas, and Spleen, each illustrated; The Oral Cavities: an Elementary and Practical Treatise on the Diseases of the Pharynx and Larynx, Dr. E. J. Moure, authorised translation by Dr. J. M. Farquharson, illustrated; Clinical Commentaries deduced from the Morphology of the Human Body, Prof. A. De Giovanni, translated from the second Italian edition by J. J. Eyre. George Routledge and Sons, Ltd.-The Family Doctor: a Dictionary of Domestic Medicine and Surgery especially adapted for Family Use, Dr. E. Barrett, illustrated; Infant Feeding by Artificial Means: a Scientific and Practical Treatise on the Dietetics of Infancy, S. H. Sadler (new edition), illustrated. Swan Sonnenschein and Co., Ltd.-Exercises for Heart Affections, based on the Nauheim Treatment, Dr. J. G. Garson, illustrated. Williams and Norgate.-International Archives of Malaria, edited by C. M. Cassel; Epilepsia : being an International Ouarterly Review devoted to the Study of Epilepsia and Kindred Diseases from Pathological, Therapeutical, and Social Aspects.

\section{Metallurgy.}

Edward Arnold.-The Dressing of Minerals, Prof. H. Louis, illustrated. A. Constable and Co., Ltd.-Welding and Cutting of Metals by the Aid of Compressed Gases and Electricity, Dr. L. A. Groth, illustrated; The Precious Metals, Dr. 'T. K. Rose, illustrated. E. and F. N. Spon, Ltd.-Metallurgical Calculations, J. W. Richards, part iii., The Metals other than Iron.

\section{TECHNOLOGY.}

A. Constable and Co., Ltd.-The Manufacture of Paper, R. W. Sindall, illustrated. Crosby Lockwood and Son.Marble and Marble Working : a Handbook for Architects, Sculptors, Marble Quarry Owners and Workers, and all engaged in the Building and Decorative Industries, W. G. Renwick, illustrated. E. and F. N. Spon, Ltd.-Sugar: Handbook for Planters and Refiners, J. A. R. Newlands and B. E. R. Newlands, illustrated.

\section{Miscellaneous.}

F. Alcan (Paris).-La Crise du Transformisme, Le Dantec. Wm. Blackwood and Sons.--Studies in European Philosophy, J. Lindsay. Chatto and Windus.-A History of Babylonia and Assyria from the Earliest Times until the Persian Conquest, L. W. King; vol. i., A History of Sumer and Akkad: being an Account of the Primitive Inhabitants of Babylonia from the Earliest Times to about B.c. 2000 ; vol. ii., A History of Babylon from the Period of the First Dynasty, about B.C. 200o, until the Conquest of Babylon by Cyrus, B.c. 539; vol. iii., A History of Assyria from the Earliest Period until the Fall of Nineveh before the Medes, B.c. 6o6. Kegan Paul and Co., Ltd.The Liturgy of Funerary Offerings, Dr. E. A. W. Budge; The Book of Opening the Mouth, Dr. E. A. W. Budge, 2 vols.; The Book of the Dead, Dr. E. A. W. Budge (new edition), 3 vols. Sir Isaac Pitman and Sons, Ltd.-Body and Soul, P. Dearmer, a Study of "Christian Science" and "Faith Healing" from the Psychological and Physiological Aspects. G. P. Putnam's Sons.-Beverages, Past and Present: an Historical Sketch of their Productions, together with a Study of the Customs connected with their Use, E. R. Emerson, 2 vols.; The Law of Psychic Phenomena: a Working Hypothesis for the Systematic Study of Hypnotism, Spiritism, Mental Therapeutics, \&c., T. J. Hudson (new edition). Swan Sonnenschein and Co., Ltd, - A translation of Hegel's Phenomenology of Mind, J. B. Baillie (Library of Philosophy); Thought and Things: a Study of the Development and Meaning of Thought or Genetic Logic, Prof. J. M. Baldwin, 3 vols., vol. iii., Real Logic; The History of Philosophy: based on the Work of Dr. J. E. Erdmann (fifth edition, revised by his son, Dr. W. Bruno Erdmann), W. S. Hough; Valuation: its Nature and Laws, Prof. Urban (Library of Philosophy); Physiological Psychology, Prof. W. Wundt, a translation of the fifth and wholly re-written German edition bv Prof. E. B. Titchener, in 3 vols., vol. ii., illustrated. The University Tutorial Press, Ltd.-Principles and Methods of Physical Education and Hygiene, W. P. Welpton; The Science of Speech : an Elementary Manual of Phonetics for 'Teachers, B. Dumville.

\section{UNIVERSITY AND EDUCATIONAL INTELLIGENCE.}

Birmingham.-Sir E. Ray Lankester, K.C.B., F.R.S., has been invited to deliver the Huxley lecture for the present session.

Dr. David Fraser Harris has been appointed lecturer in physiology to succeed Dr. Rhodes, who has resigned.

Cambridge.-The Public Orator, Dr. Sandys, spoke as follows on Thursday, March 4, in presenting Dr. Sven Anders Hedin for the degree of Doctor of Science honoris causa:-

Scandinaviae filium intrepidum, post tot pericula peregre suscepta denuo Britannis redditum, Acadèmiae totius nomine libenter salutamus. Salutamus quattuor universitatum illustrium alumnum insignem, qui et Persiam et Mesopotamiam et Caucasi montes et regiones trans mare Caspium late patentes olim peragravit, quique postea per annos decem Asiam mediam ter penetravit, ter scientiarum 
spolia plurima victor reportavit. Quid commemorem camporum praecelsorum longitudines infinitas, quid nivis aeternae solitudines immensas ab eodem perlustratas? Quid grandinis saxeae tempestatcs intolerabiles fortiter toleratas? Quid montium ignotorum labyrinthos inextricabiles identidem pererratos? Quid Trans-himalayac lacus procellosos, quid fluminum ingentium fontes audacter exploratos? Ibi originem illam tricipitem primus conspexit, e qua rex fluviorum, Brahmae filius nuncupatus; itineris longi cursum Indiam in orientalem dirigit. Idem in eadem regione rupem illam humilem primus detexit, unde Indus ipse exortus Indiam in occidentalem, Alexandri magni victoriarum olim conscius, defluit.

Atqui (ut poëtae verbis utar)

" Magnus Alexander totum cum vicerat, orbem,

Non potuit sese vincere; maius erat."

Hic autem, et sui ipsius et rerum naturae victor Alexandro felicior, etiam trans Asiam interiorem scientiarum imperium fortiter propagavit. Idem, Alexandro humanior, terram periculis plurinis plenissimam sic obiit, ut in tatis, vestigium reliquerit.

Ergo laurea nostra libenter coronamus virum a Societate Regia Geographica numismate aureo plus quam semel merito donatum, philosophiae doctorem illustrem, Sven Anders Hedin.

The next combined examination for sixty-seven entrance scholarships and a number of exhibitions at Pembroke, Gonville and Caius, King's, Jesus, Christ's, St. John's, and Emmanuel Colleges, will be held on Tuesday, December 7, and following days. Mathematics, classics, and natural sciences will be the subjects of examination at all the above-mentioned colleges. Some of the colleges allow candidates who intend to study mechanical sciences to compete for scholarships and exhibitions by taking the papers set in mathematics or natural science. Forms of application for admission to the examination at the respective colleges may be obtained as follows :--Pembroke College, W. S. Hadley; Gonville and Caius College, The Master; King's College, W. H. Macaulay ; Jesus College, A. Gray; Christ's College, Rev. J. W. Cartmell; St. John's College, The Master; Emmanuel College, The Master, from any of whom further information respecting the scholarships and other matters connected with the several colleges may be obtained. The colleges desire it to be known that any candidate for a scholarship may signify in writing his wish not to receive the emolument of the same if elected thereto, and that such candidate may be elected to a scholarship which may be honorary only and without emolument, but shall carry with it all other privileges attached to the position of a scholar. The amount thus set free will serve to increase the number of scholarships or exhibitions open to other candidates.

The syndicate appointed to obtain plans and estimates for the new museum of archæology and ethnology has reported that it has now in hand more than $10,000 l$., more than half of which has been contributed by members of the Foste: family in memory of Mr. W. K. Foster. The syndicate is of opinion that leave should be asked of the Senate to commence at once the first portion of a building which will contain, when completed, a museum, lecture-rooms, class-rooms, library, workrooms, and private rooms for the curator and staff. Some of these rooms will be available for the meetings of the Cambridge Antiquarian Society.

The special board for physics and chemistry, and the special board for history and archæology, have issued schedules for the examination in architectural studies under the following headings:-( $\mathrm{I})$ practical mathematics; (2) elementary applied mechanics; (3) strength of materials and elementary theory of structures; (4) descriptive geometry : projection of solids; (5) the principles of surveying; (6) outlines of the history of architecture of Europe and the Near East; (7) outlines of the general history of art: (8) architecture and the allied arts of the Classical period; (9) architecture and the allied arts of the Mediæval period; (Io) architecture and the allied arts of the Renaissance and Modern periods; (II) the theory of art in relation to architecture.
London.-With reference to the statement in NATURE: of March 4, that " the Senate has taken exception to the terms of reference to the Royal Commission on the University," Sir William Ramsay, as a member of the Senate. of the University, present during the whole of the meeting on March 3, requests us to make public the fact that that statement is without foundation. The note did not refer to the meeting on March 3, that being the day on which Nature went to press; and our correspondent informs us it was based upon the official announcement made in the Times and other papers on February 26 , though it failed to express exactly the substance of that announcement.

THE issue for 1909 of the "Schoolmaster's Year-book and Directory " is now available. The general character of the volume remains unaltered; the directory has been made much more complete, and the very large anount of information provided has been brought up to date. This annual work of reference continues the most convenient available source of particulars concerning every grade of secondary education for boys, and no schoolmaster should be without a copy.

IT is announced by Sience that the $40,000 l$. required to secure the gift of $120,000 l$. from $\mathrm{Mr}$. John D. Rockefeller for the Harper memorial library at the University of Chicago has now been obtained. Part of the money has been reserved for an endowment. The president of Western Reserve University announces the completion of a roo,oool. fund for the additional endowment of Adelbert College and the college for women. Of this amount 25,00ol. was offered by the General Education Board, on the condition that 75,000 l. be raised by the University. Hamline University, St. Paul, Minn., has been offered I $5,000 \mathrm{l}$. by the General Education Board of New York on the condition that it will raise three times the amount, making a total of $60,000 l$, a large portion of which is to be added to the permanent endowment of the University. The department of engineering of the University of Michigan has received a gift of the library of the late $\mathrm{Mr}$. George $\mathrm{Y}$. Wisner and a rotary engine of the value of r 400 l. from Mr. J. D. R. Lampson. The University of Virginia has completed an endowment fund of $200,000 \dot{l}$., of which half has been given by Mr. Andrew Carnegie.

THE Board of Education has now published the second part of "Statistics of Public Education in England and Wales, 1906-7-8." This Bluc-book (Cd. 4506) is concerned wholly with financial statistics. It is interesting to find that the net total expenditure during the school year 1907-8 of the Board of Education out of the Parliamentary vote was $13,272,017 l$., and that $11,129,658 l$. was expended on elementary education. Under the headings " secondary schools, pupil teachers, \&c.," the amount disbursed was $679,612 l$. To quote the summary of payments, the grants made for "technical institutions, schools of art, day technical classes, art classes, and other schools and classes for further education" reached $456,573 l$. The share of the Parliamentary vote which went to higher scientific education appears very small, as the following items show:Roval College of Science, London, 24,843l.; Imperial College of Science and Technology, 5,783l.; Geological Musoum and Geolossical Survey, $2 \mathrm{r}_{2} 255 \mathrm{l}$.; and Committce on Solar Physics, $1899 l$. These amounts probably do not quite account for the total amount which should be credited to higher scientific instruction, because fractions of the expenditure under " works and furniture" and "museums and circulation of obiects for exhibition", were probably devoted to the purposes of education in science.

THERE are many indications that eventually we shall have a science of education, and it is satisfactory to find that the number of persons engaged in educational work who are learning the value of the results of carefully and scientifically planned experiments steadily increases. The training college authorities in different parts of the country are beginning to take an active share in this important work, and the spread of scientific methods in their institutions is reflected in the second issue of the Training College Record which has reached us. Among other important articles contained in this excellent magazine we notice that by Prof. Green on experiment in education, 
in which he gives a helpful summary of the more important educational experiments inaugurated in this and other countries during 1908. Dr. Percy Nunn describes briefly a pedagogical museum which is being arranged at the London Day Training College; the arts of reading and of clear speech are discussed ably by Prof. Wyld and Principal Burrell; and Mr. H. H. Hulbert deals with the teaching of hygiene in training colleges. The other contributions similarly indicate that the age of empiricism and the blind adherence to the obiter dicta of departed writers on education is giving place to an attempt to understand by observation and by suitable tests the working of the child mind and the ways in which it is influenced by environment and other conditions.

\section{SOCIETIES AND ACADEMIES. LONDON.}

Royal Society, November 26, 1908. - " The Proportion of the Sexes produced by Whites and Coloured Peoples in Cuba." By Walter Heape.

This paper deals with data contained in publications issued by the chief sanitary officer of Cuba, 1904-5-6, in which are recorded the sex of both legitimate and illegitimate births and still-births for both classes of the population. The totals dealt with amount to 177,704 , viz. whites 135,881 , and coloured peoples 41,823 births and still-births. It is found :-

( 1 ) That there is a racial difference in the proportion of the sexes produced; for whites, 108.44 males, for coloured, ror.12 males, per 100 females. This result is in close agreement with other published statistics of both races, and shows the influence of heredity.

(2) That for both races, for both births and still-births, there is a consistent variation in the proportion of the sexes produced by legitimate as compared with illegitimate union. For whites, legitimate 109, illegitimate 105.95 males per 100 females. For coloured, legitimate, 107.73, illegitimate $97.9 \mathrm{I}$ males per roo females. Illegitimate unions result in a marked increase in the proportion of females produced, and it is claimed that they are chiefly induced by individual physiological conditions affecting the metabolic activity of the woman.

(3) That both whites and coloured experience two sharply defined breeding seasons each year; sudden, brief bursts of reproductive activity, correlated with marked climatic changes, which tend to increase individual metabolic activity. Again, at these times of greatest fertility the largest proportion of females is produced.

(4) That a considerably higher proportion of females are born in towns than in country districts, where life is associated with greater hardships.

(5) Conclusions: although heredity, in the main, governs the proportion of the sexes produced by these two races, conditions occur under which that proportion is varied, and although different in degree it is similar in character for both races. These conditions are directly associated with forces which affect the metabolic activity of the mother, and suggest the probability that the ripening and production of ovarian ova of different sexes is influenced thereby. Thus it is held that a struggle for existence is always going on among the sexual ovarian ova, and that these extraneous forces influence the result. Speaking generally, this investigation indicates that the greater the metabolic activity of the ovary the more females are produced.

January 14.- "On the Passage of Röntgen Rays through Gases and Vapours." By J. A. Crowther. Communicated by Sir J. J. Thomson, F.R.S.

A series of experiments has been made, under comparable conditions, on the behaviour of different gases and vapours with respect to the passage of Röntgen rays through them. The results obtained are thus summarised :-

(I) The amount of ionisation produced by the direct action of the primary Röntgen rays on a gas is simply proportional to the pressure of the gas. No evidence was obtained of the emission of any appreciable amount of soft secondary radiation by the gas, the ionisation being apparently due to the direct action of the primary rays.
(2) The relative ionisation in the different gases, compared with air as the standard, varies considerably with the hardness of the rays. Hydrogen and ethyl bromide show an increase as the hardness of the rays increases. Other gases remain constant or give a diminution. There is no indication of any approximation to a "density law" as the hardness of the rays is increased.

(3) The relative ionisation in a gas follows approximately an additive law. It does depend somewhat, however, on the state of combination, especially for soft rays.

(4) The absorption varies with the pressure according to an exponential law.

(5) The amount of secondary radiation emitted by different gases relative to air is, generally, approximately independent of the hardness of the primary rays. For very hard rays ethyl bromide shows a slight decrease. On the other hand, the values for methyl iodide increase fairly rapidly as the hardness of the rays is increased.

(6) The coefficient of absorption of the secondary rays emitted by a gas, in the gas itself, is not abnormal.

(7) The total ionisation in different gases is not a constant, and the relative values obtained differ with the hardness of the rays.

(8) The amount of energy required to produce an ion in different gases is different, and also varies with the hardness of the rays.

No relationship has been found between the relative ionisation and the secondary radiation, or between either, and any other known property of the gases and vapours, and the explanation of the relatively large amounts of secondary radiation emitted by ethyl bromide and its class compared with air, and of the large relative ionisations in methyl iodide, ethyl bromide, \&c., still remains to be sought.

It appears that on the whole less energy is required to produce an ion in the more ionisable gases, but the values obtained do not differ very largely, and are totally inadequate to explain the very large amounts of ionisation in these gases and vapours.

Both the ionisation and the secondary Röntgen radiation follow, at any rate approximately, an additive law. It appears, therefore, that these properties are properties of the atoms themselves, and that an explanation must be sought in their atomic structure.

February 25.-Sir Archibald Geikie, K.C.B., president, in the chair.- The statistical theory of the form of the curve of oscillation for the radiation emitted by a black body: Prof. H. A. Wilson. The view adopted in this paper is that the radiation from a black body is an irregular disturbance subject to statistical laws. It is shown that these laws can be deduced from the distribution of energy in the spectrum, and that they enable the character of the disturbance to be described. The disturbance at any instant is taken to be the sum of the displacements in the infinite number of simple harmonic vibrations of arbitrary phases which are obtained when the radiation is dispersed into a spectrum. Expressions are found for the chances that the displacement and its derivatives lie between given limits. These expressions enable the average number of zero values per $\mathrm{cm}$. of the displacement and its derivatives to be calculated. The distribution of maxima and minima is estimated, and a curve has been drawn having approximately the statistical properties deduced. The mean wave-length $\left(\lambda^{\prime}\right)$ of the radiation is defined as $2 / n_{0}$, where $n_{0}$ is the average number of zeros per cm. in the displacement curve. If $\lambda_{m}$ denotes the wave-length in the spectrum at which the energy is a maximum, it is shown that $\lambda^{\prime} / \lambda_{m}=2.5$. It is shown that the number of maxima and minima is about double the number of zero values and about half the number of points of inflection in the curve.-The flight of a rifled projectile in air: Dr. J. B. Henderson. The problem is attacked from first principles simply as a case of a moving rotating body meeting with certain resistances due to the air, and it is found that all the known phenomena are accounted for by the precessional motions of the shot, due to the tilting and friction couples which arise from the obliquity of the axis of the projectile to the direction of motion. The complete trajectory in all its details can be thus constructed from the initial conditions and the laws of resistance so soon as these are

No. 2054, VOL. 80] 